\title{
O significado da compra: desejo, demanda e o comércio do sexo*
}

\author{
Elizabeth Bernstein **
}

\begin{abstract}
Resumo
Feministas e outros acadêmicos vêm debatendo teoricamente o que exatamente é comprado numa transação de prostituição e se o sexo pode ser "um serviço como qualquer outro", mas raramente lidaram empiricamente com essas questões. Este artigo se baseia em observações de campo e entrevistas com clientes masculinos de trabalhadoras do sexo comercial e com agentes do Estado encarregados de regulá-las para investigar os significados dados a diferentes tipos de trocas sexuais comerciais. Manifestados por detenção e re-educação de clientes, apreensão de veículos, leis mais estritas sobre a prostituição de menores e a posse de pornografia com crianças, recentes esforços do Estado para problematizar a sexualidade masculina em todos os EUA e Europa Ocidental se desenvolveram ao lado de uma ética de consumo sexual descontrolada, evidenciada pela imensa demanda por pornografia, clubes de strip-tease, "lap-dancing", acompanhantes, sexo por telefone e "turismo sexual" em países em desenvolvimento. Ao situar a troca sexual comercial dentro do contexto mais amplo das transformações pósindustriais da cultura e da sexualidade, podemos começar a desvendar esse paradoxo.
\end{abstract}

Palavras-chave: Prostituição, Masculinidade, Desejo,

Mercantilização, Intimidade, Trabalho Sexual, Gentrificação.

\footnotetext{
* The Meaning of Purchase: Desire, Demand and Commerce of Sex. Ethnografhy, vol. 2(3), 2001, pp.389-420 [Tradução: Fernanda Leão; Revisão: Adriana Piscitelli]. O Comitê Editorial agradece as autorizações da autora e da Sage Publications para traduzir este artigo.

** Professora Assistente no Departamento de Sociologia no Barnard College, Columbia University, USA. elizabb@uclink4.berkeley.edu

1 N.T.: Tipo de dança, incluindo strip-tease, em que a dançarina dança quase sobre o colo (lap) do cliente. A dança pode incluir contato físico entre ambos.
} 
Desejo, demanda e o comércio do sexo

The Meaning of Purchase:

Desire, Demand and Commerce of Sex

\begin{abstract}
Feminists and other scholars have debated theoretically what exactly is being purchased in the prostitution transaction and whether sex can be "a service like any other", but they have scarcely tackled these questions empirically. This article draws upon field observations of and interviews with male clients of commercial sex-workers and state agents entrusted with regulating them to probe the meanings given to different types of commercial sexual exchange. Manifested by client arrests and re-education, vehicle impoundment, stricter laws on underage prostitution and the possession of child pornography, recent state efforts to problematize male sexuality throughout the USA and Western Europe have been developed alongside an increasingly unbridled ethic of sexual consumption, as evidenced by soaring demand for pornography, strip clubs, lap-dancing, escorts, telephone sex and "sex tours" in developing countries. By situating commercial sexual exchange within the broader context of post-industrial transformations of culture and sexuality, we can begin to unravel this paradox.
\end{abstract}

Key Words: Prostitution, Masculinity, Desire, Commodification, Intimacy, Sex-Work, Gentrification. 


\section{Elizabeth Bernstein}

De repente, o carro parte. Nos movemos outra vez, mas não estou certa de quem estamos seguindo. Aparentemente, uma mulher entrou no carro à nossa frente com um "encontro" [no vernáculo do sexo comercial, clientes pagantes são referidos como "encontros" ("dates") ou "truques" ("tricks")]. Seguimos em alta velocidade uma quadra ou duas, sobre trilhos de trem, até um trecho deserto, com poucos carros ou pessoas. De fato, a área está completamente vazia, exceto por alguns depósitos abandonados. A despeito do brilho do sol da Califórnia, a atmosfera é tensa.

Tudo acontece num piscar de olhos. Em poucos minutos, pisamos no freio, e dois dos policiais saltam. Sinalizam que eu os acompanhe.

Os outros membros da Unidade de Crimes de Rua já estão na cena. Pararam um caminhão Chevrolet azul $e$ algemaram o motorista, um homem grande, mas trêmulo, que tenta ser subserviente apesar de aterrorizado. Dois dos policiais têm suas armas apontadas para ele. Além do policial que fez a prisão, o sargento e outro policial também cercam o suspeito. Enquanto isso, as policiais chamam a passageira, Carla, de seu assento e começam a falar com ela. ${ }^{2}$ Estão tentando obter seu lado da estória para usá-lo como evidência. Carla está drogada e cansada, mas ainda lúcida. Aparentemente, é uma das numerosas prostitutas de rua que os policiais conhecem pelo nome, tendo sido presa repetidamente durante os mais ou menos dez anos em que vem trabalhando. Mas hoje ela não é o principal foco da atenção deles.

Circulo pelo local, absorvendo o drama do homem cercado, as armas expostas, as momentâneas demonstrações de força e temor. Coração acelerado, tento escutar, sentindo-me vagamente culpada por fazer parte

2 Todos os nomes e detalhes de identificação de pessoas e lojas comerciais específicas foram trocados ou omitidos para que se proteja seu anonimato. Localidades geográficas, quando incluídas, foram deixadas sem modificação a fim de respeitar a especificidade, em termos de localização, dos eventos que descrevo. 
Desejo, demanda e o comércio do sexo

disso. O policial que fez a prisão faz um monólogo rápido, ao estilo policial durão de TV:

Quero que você me diga o que aconteceu... Lembre-se, já falamos com ela, então sabemos... O que você estava pensando?... Usou camisinha?... Não? Então você gozou na boca dela?... Você pelo menos olhou para ela? Viu aquela merda nojenta que ela tinha nas mãos? Agora está espalhado em seu cacete... Você tem uma esposa ou namorada? Agora você vai para casa e passar seja lá o que você contraiu para ela. Todo homem já pensou sobre isso, mas você não precisa arriscar. Da próxima vez que estiver com tesão, por que não compra alguma pornografia e bate uma punheta?

Antes de soltar o preso, os policiais lhe dão uma citação por escrito e marcam uma data para que ele compareça diante do juiz.

Mais tarde, na mesma noite, chego a um famoso "teatro erótico" com uma amiga, cansada, mas curiosa. O teatro tem uma reputação de ser um dos mais chiques dos 14 clubes de sexo na área, onde strip-tease, lap-dance e, em período mais recente, manipulações e boquetes estão disponíveis para compra, ainda que extra-oficialmente. Passamos por um grupo de homens de negócio asiáticos $e$ chegamos à entrada. Um homem de meia-idade polidamente recebe nosso dinheiro (US\$ 45 cada) sem parecer se surpreender que tenhamos escolhido vir embora sejamos obviamente as únicas mulheres naquela noite. Uma cesta de camisinhas se destaca junto à porta.

Outra vez de maneira direta, um empregado nos acompanha numa volta pela casa, descrevendo as várias atrações. As salas têm nomes como "Clube VIP" e "Sala Luxuosa". O recinto tem pouca iluminação, mas é limpo, arrumado e um tanto frugal. $\mathrm{O}$ chão não tem tapetes, nem manchas. Nos dirigimos ao palco principal na sala dos fundos, onde uma mulher jovem, bronzeada e vigorosa, num brilhante biquíni de tiras, dança sob luzes 


\section{Elizabeth Bernstein}

estroboscópicas e disco. Ela se retorce e vira, gira e salta, abre e fecha as pernas. Seu acompanhante é um longo mastro prateado que se ergue do chão. Enquanto os homens à volta a olham, eu os examino. Eles esticam os pescoços para obter melhor visão da dançarina. Todos os assentos estão ocupados e só há espaço em pé. "Imagine voltar para casa para isso", é o arroubo de um quarentão branco, de terno preto e gravata vermelha para um de seus colegas. A performance termina e a dançarina atravessa sua audiência, enquanto os clientes acariciam a superfície de seu corpo e enfiam notas de 20 sob suas ligas.

Muitos dos clientes são extremamente jovens: abaixo de 25, talvez abaixo de 20, brancos, com bonés de baseball e com roupas esportivas. Esses contingentes vieram claramente em grupos. Aqueles entre 30 e 40 e tantos, brancos e de terno, parecem compreender outra categoria, e também se reúnem em grupos de três ou quatro. Há também os solitários - outra vez abaixo dos 50, predominantemente brancos, com salpicos de negros e latinos. Todos são hígidos, de aparência e constituição média. Pela mera aparência, parecem desmentir que a indústria do sexo se dirige aos homens mais velhos que não conseguem encontrar parceiras.

Numa sala chamada "Amsterdã ao Vivo", um palco central é circundado por um anel de pequenos cubículos rebaixados, cada um separado da área central por finas cortinas de malha negra. Esse desenho permite que as cabeças e corpos dos clientes se projetem em direção ao palco, $e$ as mulheres se projetem nos cubículos na outra direção. Uma parede circundante de espelhos acima dos cubículos significa que cada cliente pode ver os demais clientes, bem como as dançarinas. Duas mulheres jovens $e$ belas vêm para fora, ambas com cabelos brilhantes até a cintura e saltos muito altos, nuas, exceto por cintas que deixam seus seios e genitais expostos. Elas imitam um ato sexual altamente coreografado $e$ estilizado, beijando-se $e$ lambendo-se. Então, a despeito do aviso prévio de que as partes do corpo devem permanecer nos cubículos, as 
Desejo, demanda e o comércio do sexo

mulheres perguntam aos homens que os ocupam se vão querer um "show". As duas descem para os cubículos escuros onde são agarradas por mãos ávidas, desaparecendo momentaneamente de nossa linha de visão (Notas de campo, Área da Baía de San Francisco, maio de 1999).

Feministas e outros acadêmicos vêm debatendo teoricamente o que é "realmente" comprado na transação da prostituição; trata-se de uma relação de dominação? É amor, dependência, prazer? Pode o sexo ser considerado um serviço como qualquer outro? ${ }^{3}$ Mas raramente abordaram essa questão empiricamente. Este artigo se baseia em observações de campo e entrevistas com clientes de trabalhadoras do sexo e agentes do Estado encarregados de regulá-las para investigar os significados atribuídos por diferentes tipos de clientes à troca sexual comercial, e para situar tal troca dentro do contexto mais amplo das transformações pós-industriais da cultura e da sexualidade. ${ }^{4}$

Começo pelas duas paradoxais imagens etnográficas acima. A primeira descreve o fenômeno novo e crescente da detenção de clientes heterossexuais de prostitutas de rua, estratégia sem

3 Esses questionamentos e significados postulados derivam da vasta literatura da teoria feminista sobre o assunto. Para um quadro geral crítico, ver Bernstein (1999)

4 O meu foco é no desejo masculino heterossexual e em padrões de consumo o principal mercado de sexo comercial, no qual o Estado intervém, e o foco quase exclusivo do discurso estatal. Em centros urbanos turísticos, estima-se que a prostituição heterossexual abranja aproximadamente dois terços do total do mercado, enquanto encontros pagos entre homens correspondem a aproximadamente um terço (Leigh, 1994). Embora haja uma literatura em expansão sobre a emergência de mulheres que consomem imagens pornográficas (Juffer, 1998), e no fenômeno recente do turismo sexual feminino no Caribe (O'Connell Davidson, 1998), há evidências escassas de que exista, no plano doméstico, um número significativo de clientes femininas de prostituição lésbicas ou heterossexuais. Assim, não busquei incluir qualquer cliente sexual feminina na minha amostragem. A falta de tal mercado é bastante reveladora da natureza, persistentemente marcada por gênero, do consumo de sexo comercial. 
precedentes de intervenção direta do Estado na expressão do desejo sexual masculino. No final dos anos 90, pela primeira vez, cidades norte-americanas, como São Francisco e Nova York, começaram a jactar-se de taxas de detenção de clientes que se aproximavam das de prostitutas, invertendo o padrão histórico que as feministas há muito criticavam (Pheterson, 1992; Lefler, 1999). ${ }^{5}$ A segunda nos leva a um "teatro erótico", local onde atos de sexo são consumidos - legalmente e, em certa medida, culturalmente -, como casos não problemáticos de autorização sexual e vínculos masculinos.

Apesar da existência de uma ética descontrolada de consumo sexual, na Europa Ocidental e nos EUA, recentemente, o Estado tem problematizado o desejo heterossexual masculino crescentes detenções de clientes e programas de reeducação; retenção de veículos; leis nacionais e internacionais mais estritas sobre o consumo de prostituição com menores de idade e da posse de pornografia com crianças. Durante os últimos 30 anos, a demanda pelos serviços sexuais disponíveis não só explodiu como se tornou cada vez mais especializada, diversificando-se em linhas tecnológicas, espaciais e sociais. Assim, o âmbito do comércio sexual cresceu, abrangendo shows de sexo ao vivo; toda variedade de textos, vídeos e imagens pornográficas, impressas e on line; clubes fetichistas; "empórios" sexuais exibindo lap-

\footnotetext{
${ }^{5}$ As primeiras prisões de clientes nos EUA (as quais foram intermitentes $e$ escassas) seguiram uma lei de 1975, suscitada pela Declaração dos Direitos Civis Americana perante o Tribunal da Califórnia, que firmou: "o simples fato... de que homens e mulheres envolvidos em condutas sexuais proibidas não são tratados em pé de igualdade" (MacDonald, 1978:C5). Sobre o aumento dos índices de prisões de clientes em São Francisco, em meados dos anos 1990, ver Marinucci (1995a) (descrevendo um aumento de 25\% nos índices de prisões de clientes) e Marinucci (1995b) (citando estatísticas do Departamento de Polícia de São Francisco e indicando uma explosão expressiva das prisões de clientes masculinos ligados a prostituição, de 1 mil para 4,9 mil no total). Sobre a emergência de um fenômeno parecido em Nova, Iorque como parte das campanhas de "Qualidade de Vida" do prefeito Rudolph Giuliani, ver PierrePierre (1994) e Nieves (1999).
} 
Desejo, demanda e o comércio do sexo

dancing e wall-dancing ${ }^{6}$; agências de acompanhantes; contatos telefônicos e de sexo virtual; vias de strip-tease drive through; e turismo sexual organizado em países do mundo em desenvolvimento (Kempadoo e Doezema, 1998; Lopez, 2000; Weitzer, 2000a). O comércio sexual se tornou uma indústria multifacetada, de bilhões de dólares, produzida por desenvolvimentos em outros setores da economia global - cadeias de hotéis, provedores de telefonemas de longa distância, companhias de cabos e tecnologia de informação - $e$, por sua vez, produzindo impactos em todos esses setores. ${ }^{7}$ Assim como a disponibilidade de filmes pornográficos em vídeocassetes levou diretamente à introdução dos aparelhos de vídeo domésticos, a pornografia em CD-ROM e na internet foi responsável pela aceitação e popularização dessas novas tecnologias (Schlosser, 1997; Lane, 2000). Segundo empresas de pesquisa na internet, um terço das pessoas que navegam na internet visitam sites pornográficos (em geral durante o horário de trabalho) e, em 1997, quase todos os sites de conteúdo pago na rede eram pornográficos (Learmonth, 1999; Prial, 1999; The Economist, 2000).

Esses desenvolvimentos sociais contraditórios revelam uma tensão entre o sexo como recreação $e$ o impulso normativo para um retorno ao sexo como romance, uma contrapartida cultural do que pode ser encontrado na emergência simultânea do Viagra e de tratamentos em 12 passos para a dependência masculina do sexo. "Sexo" como imperativo cultural e busca técnica, agora livre dos limites da emoção $e$ do romance, e a moldagem de comportamento erótico sem ligações emocionais como

${ }^{6}$ N.T.: Tipo de dança, incluindo strip-tease, feita contra uma parede.

7 Como destacou Eric Schlosser (1997:44), "a maioria dos lucros gerados pela pornografia, atualmente, são obtidos por empresas não associadas tradicionalmente com a indústria do sexo - pequenas vídeo-locadoras, companhias de telefonia de longa distância como a AT\&T, empresas de canais a cabo como a Time Warner e a Tele-Communications Inc e cadeias hoteleiras como Marriot, Hyatt e Holiday Inn que, ao que consta, ganham milhões de dólares por ano fornecendo filmes de conteúdo adulto a seus hóspedes". 
"dependência" patológica são produtos dos mesmos lugares e tempo. O objetivo deste artigo é desvendar esse paradoxo.

Alguns atribuíram as recentes tentativas de reformar a sexualidade masculina a ganhos do feminismo da segunda onda, $e$ até mesmo descreveram um deslocamento do estigma social da vendedora para o comprador dos serviços sexuais (Kay, 1999). No entanto, a influência de fatores estruturais mais amplos foi negligenciada na maioria das discussões. De fato, tanto a intervenção do Estado em práticas heterossexuais masculinas (freqüentemente nas camadas de classe menos favorecidas), quanto as novas marcas de gênero no estigma sexual em certas frações da classe média, podem ser ligadas a algumas das transformações mais amplas que produziram o florescimento da demanda por serviços sexuais. No mundo que se industrializava no século XIX e começo do XX, o "errado" na prostituição era alocado na própria prostituta ${ }^{8} e$, nas obras clássicas da ciência social, a prostituição como instituição social foi vista como a metáfora por excelência da exploração inerente ao trabalho assalariado (Marx, 1978 [1844]; Engels, 1978 [1884]; Simmel, 1971 [1907]. Contudo, ao final do século XX, com a mudança de uma economia baseada na produção para uma economia baseada no consumo, o foco da crítica moral e da reforma política é gradualmente deslocado; a prostituta é normalizada, seja como "vítima" ou como "trabalhadora do sexo", enquanto a atenção $e$ a sanção é afastada das práticas de trabalho em direção do comportamento do consumidor.

8 Apesar do fato de que a prostituição masculina também estava presente em centros urbanos nesse período, nos discursos acadêmicos, médicos-psicológicos e políticos os trabalhadores do sexo masculinos foram geralmente englobados na nova bandeira, socialmente mais destacada, de "homossexuais" (Weeks, 1997 [1981]).

9 É irônico que movimentos pelos direitos das prostitutas tenham buscado legitimidade através da bandeira do "trabalho sexual" (Jenness, 1993), considerando que, para Marx e outros críticos socialistas pioneiros, o problema do trabalho assalariado, enquanto "trabalho", era precisamente que era semelhante à prostituição (Marx, 1978 [1844]:103). 
Desejo, demanda e o comércio do sexo

No que segue, primeiro traço o esboço de uma breve genealogia dos discursos acadêmico e político em torno do desejo sexual masculino e da demanda de consumo que se desenvolveu no século passado. Em seguida levo o leitor a uma variedade de situações onde se localiza o consumo sexual comercial, a fim de explorar os significados e motivações que os clientes contemporâneos atribuem a suas próprias atividades. Na última seção, contrasto esses quadros com recentes tentativas de agências estatais de reformulação da demanda, na esteira de um mercado sexual que cresce rapidamente e se diversifica.

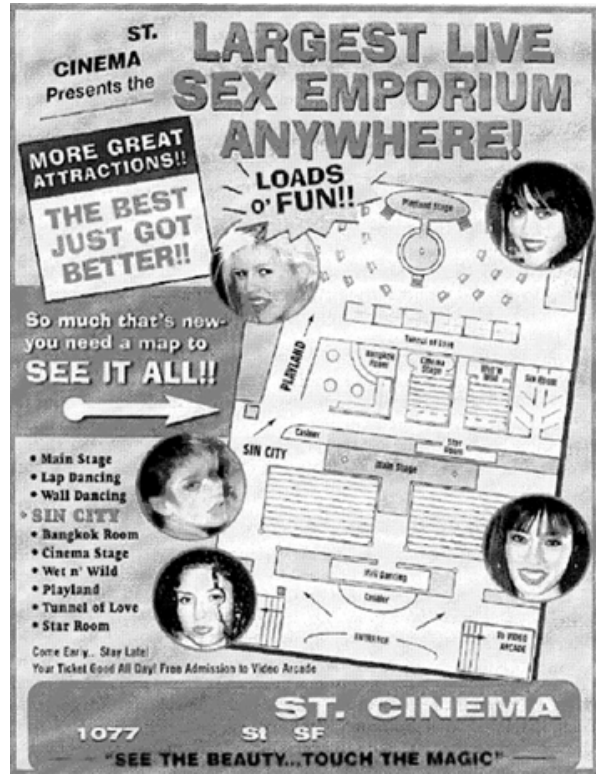

Figura 1 - Nos últimos anos, o comércio sexual se expandiu para além da prostituição, abarcando uma série mais ampla de produtos e serviços sexuais, como ilustra este anúncio na web de um "empório sexual" em São Francisco. 
Elizabeth Bernstein

Em geral, minha discussão se baseia em 15 entrevistas em profundidade com consumidores de sexo, 40 entrevistas em profundidade com trabalhadores sexuais masculinos e femininos, revisão de jornais locais de sexo e outros meios impressos e eletrônicos, e trabalho de campo etnográfico em mercados sexuais realizado em seis cidades do norte da Califórnia e da Europa Ocidental ao longo de cinco anos. ${ }^{10}$

${ }^{10}$ Doze das entrevistas com clientes foram presenciais, com duração de uma a quatro horas cada. As três entrevistas restantes foram realizadas pelo telefone. Os entrevistados eram residentes de três diferentes cidades da Costa Oeste e foram recrutados através de indicações de informantes que eram trabalhadoras do sexo $e$ através de anúncios postados em jornais locais de teor sexual - heterossexual $e$ homossexual masculino -. Eles eram consumidores de uma série de produtos e serviços sexuais, incluindo casas de massagem, trabalhadores do sexo independentes, prostitutas de rua, agências de escorts, tele-sexo e clubes de striptease. Dos 15 entrevistados, 14 eram brancos, e o $15^{\circ}$ se auto-declarava mexicano. Se, em uma certa medida, isso reflete a composição racializada e estratificada dos consumidores da indústria do sexo (ver nota 14 abaixo), outro ponto relevante pode ter sido meus meios de contatar os participantes. Amostragens bola-de-neve formaram-se através de trabalhadoras do sexo brancas, educadas e de estabelecimentos fechados, que tendiam a apresentar uma maior renda e uma clientela predominantemente branca como elas próprias. Entrevistas em profundidade com trabalhadoras do sexo, tanto de estabelecimentos indoor como de rua, que duraram de uma a quatro horas foram realizadas presencialmente em inglês: na área da Baía de São Francisco; Amsterdam, na Holanda; Gothenburg, na Suécia; Oslo, na Noruega e Copenhagen, na Dinamarca. Foram consultadas mais de 1500 páginas de materiais de mídia impressa e online entre1995 e 2000. A pesquisa online envolveu uma análise de websites e salas de bate-papo onde profissionais do sexo fazem propaganda e se consultam entre si, e sites e fóruns onde os clientes trocam experiências e outras informações. O campo etnográfico consistiu em observações in loco e conversas informais com participantes de uma gama diversa de espaços de comércio sexual, incluindo clubes de sexo, calçadas da prostituição de rua, casas de massagem e bordéis, assim como aparatos da justiça criminal, reuniões municipais de elaboração de políticas públicas e agências de serviço social. Entre 1994 e 1996, atuei como observadora participante na Força-Tarefa de São Francisco sobre Prostituição, criada pelo Comitê de Supervisores para analisar e corrigir políticas sobre prostituição em São Francisco. Através da associação à Força-Tarefa, fui apresentada às principais ativistas pelos direitos das prostitutas da cidade, representantes de 
Desejo, demanda e o comércio do sexo

\section{A explicação da demanda sexual comercial}

A literatura acadêmica sobre a prostituição, e sobre as políticas sociais, usualmente, abarca os variados fenômenos do comércio sexual através de um foco estreito na etiologia, tratamento e simbolismo social da prostituta. Embora as cruzadas pelo puritanismo dos EUA do século XIX tenham procurado problematizar a sexualidade masculina, sua campanha para substituir o duplo padrão moral prevalecente por um único padrão feminino, que seria codificado na política do Estado, teve pouco sucesso (Luker, 1998). Depois da era progressista ${ }^{11}$, a atenção social ou acadêmica à prostituição diminuiu, $e$ teorias funcionalistas e psicanalíticas retomaram o duplo padrão moral, $e$ tornaram a prostituição não só não-problemática para a clientela masculina como também estruturalmente integrante da instituição do casamento (Davis, 1937; Greenwald, 1958). ${ }^{12}$ Nas décadas de 70 e 80, tanto a sociologia do desvio como a teoria feminista percebiam a prostituta (mas não o cliente) como um precipitado carregado da simbologia de correntes sociais mais amplas. Embora algumas feministas da segunda onda tenham criticado a falta de atenção aos clientes (McIntosch, 1978; Hoigard e Finstad, 1986; Hobson, 1990), assim como ao duplo padrão sexual que o escorava, foi só durante a última década que surgiu uma literatura empírica com foco continuado nos clientes.

bairro e agentes oficiais do governo e da polícia, incluindo muitos dos membros que, mais tarde, viriam a desempenhar um papel principal no desenvolvimento da "John School".

${ }^{11}$ O período entre 1880 e 1920, na história dos Estados Unidos, tem sido tratado como a "Era Progressista", marcando a transição entre a sociedade pré-industrial parental e a nação moderna industrial (Luker, 1998).

${ }^{12}$ Em alguns textos, podem aparecer lado a lado construções de consumo sexual normalizadas e patologizadas. Greenwald (1958), por exemplo, apresenta uma "tipologia john", na qual o cliente "compulsivo" é patologizado, enquanto o cliente "ocasional" é normalizado. 
Nos últimos 15 anos, uma nova geração de pesquisadoras feministas empreendeu um pequeno, mas crescente, número de estudos qualitativos do comportamento dos clientes. ${ }^{13}$ Entretanto, sob o influente (ainda que problemático) trabalho de Kinsey (1948), e atendendo a recomendações feministas de que dever-seia dar visibilidade aos clientes, pesquisadores quantitativos começaram a correlacionar a inclinação masculina em procurar prostitutas com outros padrões sócio-demográficos. Analisando dados, de 1993, da National Health and Social Life Survey da Universidade de Chicago, os pesquisadores Eliot Sullivan $e$ William Simon consideraram que fatores como idade, experiência militar, educação e background étnico/racial prediziam, significativamente, em termos estatísticos, a compra de sexo comercial (Sullivan e Simon, 1998). ${ }^{14}$ Mostrou-se que a inclinação ao sexo comercial variava sistematicamente de acordo com diversas disposições atitudinais, inclusive "problemas sócioemocionais", medidos por sentimentos de insatisfação física $e$ emocional, por sentir-se não desejado e sexualmente insatisfeito e, ainda mais interessante, por "não fazer sexo como uma expressão de amor" (Sullivan e Simon, 1998:152). Ela também foi correlacionada com uma visão "mercantilizada" da sexualidade, medida pelo número de parceiras sexuais, uso de pornografia e a

\footnotetext{
${ }^{13}$ Os estudos relevantes incluem Månsson, 1998; Prieur e Taksdal, 1993; Allison, 1994; Hart, 1994; e Prasad, 1999.

${ }^{14}$ Como é freqüente na literatura, Sullivan e Simon relacionam "sexo pago" estreitamente com clientes de prostitutas. Entre as descobertas mais proeminentes de Sullivan e Simon consta que a taxa de consumo de prostituição é maior para homens entre 53 e 60 anos, que o serviço militar aumenta em $23 \%$ as chances de um homem vir a consumir sexo pago, que o efeito geral da educação é aumentar a probabilidade de financiamento da prostituição, e que homens afroamericanos e hispânicos são duas vezes mais propensos a recorrer a prostitutas do que um homem branco $(1998: 139,140,150)$. Essa alegação final talvez seja a mais questionável, dadas as evidências contraditórias apresentadas em outras considerações já publicadas, assim como na minha própria pesquisa sobre o direcionamento da indústria do sexo no norte da Califórnia a consumidores brancos e asiáticos (Flower, 1998; Bernstein, 2001).
} 
Desejo, demanda e o comércio do sexo

crença de que é preciso ter sexo logo que se tem uma ereção (Monto, 2000).

Finalmente, o comportamento dos clientes aparece cada vez mais como componente chave de estudos qualitativos mais amplos sobre a troca sexual comercial (Hoigard e Finstad, 1986; McKeganey e Barnard, 1996; Flowers, 1998; O"Connell Davidson, 1998). Com base em dados de campo e entrevistas, esses pesquisadores geraram tipologias de motivações de clientes $e$ consumidores. Enquanto a pesquisa sobre as prostitutas fora guiada por questões de etiologia (como ela ficou assim, por que uma mulher faria isso?), essa outra sublinha diferenças entre homens, mas tende a assumir como dado seu status de compradores. As principais motivações identificadas por esses autores incluem o desejo dos clientes por variação sexual, o acesso sexual a parceiras com as idades, características raciais $e$ físicas preferidas, a atração de um encontro sexual clandestino $e$ "sem emoções", solidão, problemas matrimoniais, a procura de poder e controle, o desejo de ser dominado ou de envolver-se em atos sexuais "exóticos" e a excitação de violar tabus. Embora provocativa, e perceptiva, essa literatura muitas vezes deixou de explicar os motivos dos clientes na sua especificidade histórica, ou de ligar esses motivos a instituições sociais e econômicas que poderiam estruturar as relações de dominação de gênero implicadas por muitas das categorias explicativas acima. Em geral, as tipologias são apresentadas como se estivessem baseadas em distintos atributos de uma masculinidade trans-histórica e estável. Duas notáveis exceções a essa tendência são os recentes trabalhos sobre o comportamento dos clientes da antropóloga Anne Allison (1994) e da socióloga Monica Prasad (1999).

Em Nightwork, etnografia de um "clube de acompanhantes" de Tóquio, onde belas jovens servem bebidas a homens de negócios, acendem seus cigarros, flertam provocativamente $e$ disponibilizam seus corpos para serem apalpados, tudo às custas do negócio, Allison parte da teoria da Escola de Frankfurt para argumentar que 
a convergência de jogo e trabalho, e do jogador e do trabalhador, suposta e pressuposta pela instituição da companhia paga como entretenimento, é um elemento de qualquer sociedade progredindo através das últimas fases do capitalismo (Allison, 1994:23).

De acordo com Allison, a participação de homens de negócios japoneses no mizu shobai, ou vida noturna erótica, assim como sua distância emocional de suas esposas e famílias epitomiza essa tendência histórica. Enquanto isso, na "Moralidade do Intercâmbio de Mercado", artigo baseado em entrevistas por telefone com homens consumidores de sexo, que associa a distinção clássica articulada por Karl Polanyi e Marshall Sahlins entre sociedades mercantis e pré-mercantis, Prasad argumenta que o intercâmbio da prostituição carrega consigo uma forma de moralidade específica das sociedades de consumo de massa. Suas entrevistas revelam que:

[os] consumidores conduzem o intercâmbio da prostituição de formas que não são muito diferentes de como a maioria dos intercâmbios de mercado são conduzidos hoje: informações sobre prostituição não se restringem a uma elite, mas estão amplamente disponíveis; configurações sociais enquadram a interpretação dessa informação; a criminalização da prostituição não dificulta de maneira particular o intercâmbio; e o fato do intercâmbio continuar ou não é freqüentemente ditado pela boa condução do negócio. Em resumo, de acordo com esses entrevistados, no capitalismo tardio da América o sexo é intercambiado quase como qualquer outro bem (Prasard, 1999:188).

[Notando que seus entrevistados]

apreciam o "intercâmbio de mercado" do sexo porque ele carece da ambigüidade, da dependência do status e da potencial hipocrisia que eles percebem no "intercâmbio como dádiva" do sexo, característico dos relacionamentos românticos

[conclui que no] 
Desejo, demanda e o comércio do sexo

fervoroso mercado livre das décadas de 1980 e 1990, o amor romântico algumas vezes podia estar subordinado $e$ ser julgado desfavoravelmente em relação aos prazeres do erotismo mais neutros e facilmente intercambiáveis (Id. ib.:1999:181, 206).

Diferente de muitas abordagens sobre clientes sexuais, as contribuições de Allison e Prasad situam o consumo sexual no contexto de um campo expandido e normalizado de práticas sexuais comerciais. Suas análises começam a revelar um deslocamento, de um modelo de comportamento sexual relacional para outro, recreativo, uma reconfiguração da vida erótica, na qual a busca de intimidade sexual não é dificultada, mas facilitada por seu lugar no mercado. ${ }^{15}$

\footnotetext{
${ }^{15}$ Em A Organização Social da Sexualidade, Laumann et alii utiliza os termos relacional e recreativo para designar diferentes orientações normativas em relação à conduta sexual (1994). Me utilizo de ambos os termos para fazer uma distinção entre diferentes modelos normativos e indicar sucessivas configurações historicamente específicas da vida sexual e emocional. Historiadores sociais têm atrelado o modelo relacional (também referido como "amoroso" e "de companheirismo") ao advento do romance moderno a da família nuclear às baias do capitalismo, contrastando-os com a orientação procriativa prototípica da sociedade pré-industrial (Fass, 1977; D’Emilio, 1983; Luker, 1984). Alguns teóricos sociais têm apontado para a emergência de uma segunda mudança de paradigmas da sexualidade, ocorrendo massivamente por volta dos anos 1970, nas quais a sexualidade deriva seus sentidos principais do prazer e da sensação, e deixa de ser exclusivamente de domínio marital ou de relacionamentos duradouros. Essa segunda clivagem, que eu chamo de paradigma recreativo da sexualidade, tem sido recorrentemente descrita como "normalização" do sexo (Castells, 1996), "eros sem limites" (Seidman, 1991), "a revolução erótica pósmoderna" (Bauman, 1998) e a "ética da diversão" (Bourdieu, 1984). Contrastando a sexualidade recreativa com a relacional, busco distinguir a primeira dos resíduos românticos e associações extra-sexuais que usualmente acompanham a noção de um "relacionamento", mas eu não pretendo sugerir que esteja alheio a um componente intersubjetivo significativo.
} 


\section{Os contornos subjetivos da intimidade como mercadoria}

Estou muito tempo sozinho, estou acostumado a isso, mas às vezes eu anseio por contato físico. Eu preferiria tê-lo com alguém que eu não conheço, porque alguém que eu conheço vai querer ter mais. Você acaba solitário. Eu estou saindo com uma garota agora. Eu gosto da atenção. Mas, sintetizando, é isso. Eu acho [a prostituição] excitante, tipo uma diversão. É incrível que exista. Mais pessoas participariam se não fosse ilegal. Muitas frustrações de ambos os sexos poderiam ser eliminadas (Don, 47, pintor de casas).

Eu me sinto culpado toda vez que traio minha esposa. Eu não sou um psicopata. Tento esconder o máximo possível. Eu tive um caso não-profissional uma vez. Foi agradável, $e$ íntimo, e eu não tive que pagar! Mas isso me fez sentir-me mais culpado, bagunçando a vida de outra pessoa, mesmo ela sabendo que eu era casado. Você nunca tem que se preocupar com isso quando está pagando. Por natureza, eu sou conservador, mas eu acredito na liberdade de escolha. Se uma mulher quer fazer isso, mais poder a ela! Ela está proporcionando um serviço. Eu não estou explorando-a. Exploração seria se eu encontrasse uma garota fogosa de 25 anos, que não sabe de nada da vida e a levasse para uns almoços e depois para a cama (Steve, 35, gerente de seguros).

Minha esposa nunca entendeu meu desejo por fazer isso. Eu não tenho nenhum problema com a minha esposa. Nós temos uma boa vida sexual. Tem um restaurante vietnamita na $6^{\mathrm{a}} \mathrm{com}$ a Market que eu amo, mas eu não quero comer lá todos os dias (Rick, 61, processador de dados).

Eu comecei a sair com acompanhantes em uma época em que não tinha muitas ocasiões para conhecer mulheres. Eu me sentia isolado. Meus amigos tinham se mudado, eu estava ficando desmotivado. É mais real e humano do que ficar batendo punheta sozinho. Minha preferência era escolher mulheres para ter sexo casual. Como isso não estava acontecendo, eu adquiri o hábito. Era tão fácil (Dan, 36 , analista de pesquisa). 
Desejo, demanda e o comércio do sexo

Entre os diversos temas presentes nos relatos dos clientes sobre suas motivações para obter serviços sexuais pagos há uma conexão que contraria o intuitivamente esperável. Como constataram Monica Prasad e Anne Allison, para um crescente número de homens não há antítese alguma entre a expressão erótica e o ethos do mercado. De fato, narrativas de consumidores de sexo contemporâneos desafiam a oposição cultural-chave entre público e privado que tem ancorado o capitalismo industrial moderno.

Teóricas do gênero, algumas vezes, têm considerado o crescimento recente da indústria do sexo comercial como uma reafirmação reacionária da dominação masculina em resposta aos ganhos do feminismo da segunda-onda (Giddens, 1992; O"Connell Davidson, 1998) ou como uma compensação do enfraquecimento de poder econômico masculino na esfera pública pós-industrial (Kimmel, 2000). Nesses cenários, o papel do sexo comercial é prover o cliente com um mundo de fantasia de subserviência sexual e com uma abundância que neutraliza os reais déficits de poder masculino experienciados no cotidiano. Sem contestar essas considerações, gostaria de sugerir que a procura masculina de intimidade sexual mediada pelo mercado está orientada por um conjunto adicional de transformações históricas.

Argumentos compensatórios, apresentados por O'Connell Davidson, Giddens, Kimmel e outros, se baseiam na premissa implícita de que o sexo comercial abastece necessidades que seria preferível satisfazer em um relacionamento íntimo na esfera privada do lar, onde essa satisfação seria mais plena. Contudo, para muitos clientes sexuais, o mercado é experienciado como elemento que torna mais atraente, e facilita, o acesso a formas desejadas de atividade sexual não-doméstica. Isso continua sendo verdadeiro mesmo quando o cliente deseja um encontro íntimo genuíno, mas delimitado, em termos emocionais, a experiência de ser mimado e "atendido", participar em uma ampla variedade de breves relacionamentos sexuais, ou um interlúdio erótico, que é "mais real e humano" do que seria satisfazer-se sozinho. A visão 
pouco original de que a sexualidade tem sido "mercantilizada" $e$, consequentemente, diminuída -, como tudo no capitalismo tardio (Lasch, 1979), não faz justiça à miríade de maneiras em que as esferas pública e privada, da intimidade e o comércio têm se interpenetrado $e$, por conseguinte, se transformado mutuamente, tornando o mercado de consumo pós-industrial uma arena privilegiada para garantir uma variedade de conexões interpessoais que contornam essa dualidade.

Para muitos clientes, uma das principais virtudes do intercâmbio comercial de sexo é a natureza clara e delimitada do encontro. Em épocas históricas anteriores, esse caráter "delimitado" pode ter proporcionado aos homens uma oferta sexual não problemática e disponível de imediato, para ser adicionada à existência de uma esposa pura e assexuada na esfera doméstica. O peculiar das narrativas de clientes contemporâneos é a preferência, explicitamente declarada, por esse tipo de associação íntima, delimitada, sobre outras formas relacionais. $\mathrm{O}$ sexo pago não é uma substituição melancólica para algo que idealmente se escolheria obter em uma relação romântica nãomercadológica, nem o resultado inevitável de um duplo padrão tradicionalista Madonna/vadia. Don, um homem de 47 anos de Santa Rosa, Califórnia, que nunca casou, assim descreveu as virtudes do encontro sexual pago:

Eu realmente gosto muito de mulheres, mas elas estão sempre tentando me forçar a um relacionamento. Sou um cara legal e percebo acontecer essa coisa massacrante. No momento, tem uma mulher, ela é bonita, agradável, mas se eu fizer amor com ela, ela vai querer ter um relacionamento. Mas estou bastante acostumado a viver sozinho. Eu vou e venho quando quero, faço a limpeza quando quero. Eu amo as mulheres, me divirto com elas, elas se sentem confortáveis quando estão comigo. Sempre tive muitas amigas. Eu paquero e converso com elas, mas geralmente não dou o passo seguinte, porque isso acaba em confusão! 
Desejo, demanda e o comércio do sexo

Perde-se muito se tentamos subsumir as declarações de Don sob diagnósticos pop-psicologizantes, como "medo de intimidade", ou mesmo sob um descritor social-psicologizante, dissimuladamente moralista, como "técnicas de neutralização" (Sykes and Matza, 1957). Na preferência de Don por uma vida construída para viver sozinho, a intimidade se dá através de amizades próximas e encontros sexuais pagos, seguros e controlados; vemos também a evidência do desentranhamento do indivíduo (masculino) do nexo entre sexo e romance da família nuclear privatizada. Este é um exemplo concreto da profunda reorganização da vida pessoal, cuja ocorrência, nos últimos trinta anos ou mais, tem sido notada por diversos analistas sociais (Swidler, 1980; Giddens, 1992; Hochschild, 1997). ${ }^{16}$ As transformações demográficas durante esse período, como o declínio das taxas de matrimônio, a duplicação da taxa de divórcio e um aumento de $60 \%$ no número de núcleos domésticos unipessoais, vêm gerando um novo conjunto de

\footnotetext{
${ }^{16}$ A Transformação da Intimidade de Giddens (1992) emprega um modelo "compensatório" da participação masculina no sexo comercial, ao mesmo tempo em que descreve reconfigurações mais gerais em paradigmas da intimidade do capitalismo tardio. Giddens apresenta o termo "sexualidade plástica" referindo-se a um novo paradigma do erotismo não-reprodutivo, em princípio recíproco $e$ igualitário, e subjetivamente experienciado como propriedade do eu. A sexualidade plástica é a contrapartida erótica do "relacionamento puro", um relacionamento que se estabelece pela intimidade que proporciona a ambos os parceiros. Diferentemente do modelo de sexo recreativo, que aqui apresento, a "sexualidade plástica" de Giddens ainda está essencialmente ligada uma noção de relacionamentos românticos duráveis e que se dão na esfera privada. Giddens usa o termo "sexualidade episódica" para referir ao que para ele é um desdobramento cultural menos significativo, mas mais problemático. A sexualidade episódica é de caráter masculino, de natureza compulsória e pretende neutralizar a relativa emancipação das mulheres $e$ as ansiedades estimuladas pela ameaça da intimidade que está contida em um relacionamento puro. Assim, a sexualidade episódica freqüentemente se expressa em práticas de sexo como mercadoria, como é o consumo de pornografia.
} 
disposições eróticas, as quais o mercado está bem preparado para satisfazer. ${ }^{17}$

Uma vantagem adicional dos encontros sexuais mediados pelo mercado foi articulada por Steve, gerente de seguros, casado, de 35 anos, que vive em um subúrbio de classe-média na Califórnia. Frustrado com o relativo rareamento das relações sexuais com sua esposa, desde o nascimento de seu filho, Steve decidiu buscar sexo em outros lugares. Embora haja elementos na história de Steve que invoquem o duplo padrão sexual de outros tempos, seu arrazoamento durante nossa entrevista permitiu perceber um novo deslocamento. Para Steve, o encontro sexual mediado pelo mercado é moral e emocionalmente preferivel em relação ao "caso amoroso não-profissional", em função do efeito dissipador de confusões do pagamento. Apesar de se caracterizar como "conservador por natureza", Steve incorporou em seu discurso uma ampla dose da retórica acerca de direitos das trabalhadoras do sexo, descrevendo a escolha profissional de suas "provedoras de serviço" pagas com uma reverência palpável. Desafiando as críticas feministas que vêem a indulgência sexual masculina como "exploradora", ele concluiu que a verdadeira exploração reside muito mais na falta de honestidade emocional, característica do paradigma da sedução anterior ao mercado, do que nas claras transações de mercado, envolvendo dinheiro-porsexo, das quais ele participou.

Outros clientes insistiram que seu consumo na economia do sexo comercial de forma alguma resulta em problemas ou

\footnotetext{
${ }^{17}$ Até 1988, aproximadamente um terço dos núcleos domésticos americanos eram unipessoais. Nos países europeus ocidentais, os núcleos domésticos unipessoais foram o tipo de núcleo doméstico que cresceu mais rapidamente desde os anos 1960, de 25\% (no Reino Unido) a 36\% (na Suécia) da população vivendo sozinha. Nos Estados Unidos, a porcentagem de adultos solteiros cresceu de 28 para 37\% entre 1970 e 1988 (para um relatório completo das mudanças recentes na demografia social dos EUA e da Europa ocidental, ver Bureau do Censo dos EUA, 1989, 1992; Sorrentino, 1990; e Kellog e Mintz, 1993).
} 
Desejo, demanda e o comércio do sexo

carências em suas relações sexuais mais importantes. ${ }^{18}$ Rick, um processador de dados de 61 anos de São Francisco, enfatizou que seu relacionamento sexual com sua esposa estava bom, $e$ comparou seu desejo por sexo pago com mulheres diferentes a outras experiências de consumo menos problemáticas socialmente: "Tem um restaurante vietnamita na $6^{\mathrm{a}}$ com a Market que eu amo, mas eu não quero comer lá todos os dias". A declaração de Rick pode ser lida como uma variante do argumento clássico que a prostituição é uma expressão do "apetite natural" masculino - perspectiva, como a de Steve citada acima, certamente baseada na noção do duplo padrão sexual. Como destaca Carole Pateman (1998:198), em tais argumentos "a comparação, invariavelmente, é feita entre a prostituição e a provisão de alimentos". Entretanto, é significativo que a justificativa explícita de Rick para consumir prostitutas foi menos vista como impulsos biológicos essenciais do que como uma simples escolha de consumo. A preferência declarada de Rick por variedade pressupõe um modelo subjacente de sexualidade, no qual a expressão sexual não necessariamente está relacionada com uma relação de intimidade, e no qual a diversidade de parceiras sexuais e experiências não é meramente substitutiva, mas sim desejável por si mesma.

Na mesma direção, Stephen, um escritor de 55 anos de São Francisco, descreveu uma vida excitante e aberta a novidades, em termos sexuais, em casa, com aquela que foi sua parceira doméstica por oito anos. Como complemento a isso, ele optou por

\footnotetext{
${ }^{18}$ Embora eu não tenha falado diretamente com as parceiras dos clientes, perguntei aos meus entrevistados se suas parceiras estariam inclinadas a enxergar suas atividades sexuais comerciais como eles próprios as viam. Notavelmente, a maioria dos homens informou que optaram por não contar às suas parceiras sobre suas atividades. As parceiras que tomaram conhecimento do fato tiveram reações que iam da aceitação com rancor à dor e reprovação, fornecendo evidências maiores da dimensão de que homens (vistos como objetos de desejo) e mulheres (tidas como objetos intercambiáveis) heterossexuais podem ter interesses divergentes no que diz respeito ao comércio de sexo.
} 
ter encontros sexuais mensais pagos, envolvendo dançarinas exóticas e prostitutas transgênero que eram "divertidas" $e$ "fascinantes". "Às vezes é um contato realmente agradável, o jeito como elas me tocam, como se movimentam, mas não é para algo que eu não possa ter em casa", ele explicou. Stephen continuou explicando em detalhes algumas de suas motivações para consumir prostitutas:

Quando cresci, eu era mais novo e mais baixo do que todo mundo, e convencido de que eu não era sexualmente desejável para ninguém. Na escola eu estava dois anos adiantado, um nerd total. A idéia de que essas mulheres glamorosas querem me persuadir a fazer sexo com elas é incrivel. Eu entendo que não é pela minha aparência. Eu nunca conseguiria que tantas mulheres esplêndidas fossem sexuais comigo se eu não pagasse.

Entrevistados como Stephen e Rick desafiam o pressuposto da segunda-onda feminista de que a prostituição existe, sobretudo, para satisfazer as demandas sexuais que fazem mulheres não-profissionais se sentirem desconfortáveis ou inibidas (Rosen, 1982:97). Se o sexo comercial é compensação por algo, isso não remete a aspectos que faltam nos relacionamentos domésticos significativos desses homens. No lugar disso, no marco da virada histórica do "papel de bom provedor" para a "filosofia Playboy", sem restrições e consumista, muitos clientes sexuais se sentem merecedores do acesso a múltiplas parceiras atraentes (Ehrenreich, 1983). Nos termos dessa nova lógica cultural da dominação masculina, os clientes conjuram o mercado sexual, como se fosse o grande equalizador social onde o capitalismo de consumo democratiza o acesso a bens e serviços que em uma era anterior teriam sido área exclusiva de uma elite restrita. ${ }^{19}$

${ }^{19}$ Embora lamentando, mais do que celebrando, Marx foi o primeiro a notar a irônica capacidade niveladora das transações mercantis: "Aquilo que existe para mim através da mediação do dinheiro - aquilo pelo qual posso pagar (i.e., o que o dinheiro pode comprar), aquilo me define, o dono do dinheiro. O que é 
Desejo, demanda e o comércio do sexo

Eis aqui um relato das atividades comerciais sexuais de outro homem, desta vez, de uma sala de bate-papo na Internet para clientes de clubes de strip-tease:

Eu finalmente consegui ter bons momentos na cidade à beira da Baía, méritos do meu chefe, que decidiu que eu precisava comparecer semana passada lá para uma conferência. Pois bem, munido com um vasto conhecimento dos lugares do local, embarquei em uma semana de entretenimento e diversão. Infelizmente, eu acabei gastando tempo demais com os colegas da conferência e só fiz três viagens aos clubes. Eu tive momentos absolutamente incríveis...

No primeiro clube, eu me dirigi para a Sala Patpong ${ }^{20} \mathrm{com}$ Jenny, que me perguntou no que eu estava interessado. Eu disse que umas duas lap dances sem roupa eram uma boa idéia e perguntei o seu preço: US $\$ 60$ cada. Tudo bem, sem problemas. Eu liberei a grana. Depois das duas longas danças ela me ofereceu um boquete por mais US $\$ 120$. Eu disse que isso seria o paraíso e lhe entreguei o dinheiro. ...Foi uma experiência absolutamente celestial. Gastei US $\$ 30 \mathrm{em}$ taxas adicionais, US $\$ 10$ em gorjetas, US $\$ 240 \mathrm{com}$ Jenny, e US\$300 com uma outra garota chamada Tanya, no total US $\$ 580$. Nada mal para um pouco mais de duas horas de diversão ilícita. Eu estou acostumado a pagar isso

propriedade do dinheiro é de minha posse, e poderes essenciais - as propriedades e os poderes do seu dono. Assim, aquilo que sou e que sou capaz de fazer, de forma alguma, está determinado pela minha individualidade. Sou feio, mas posso comprar para mim mesmo as mulheres mais belas" (Marx, 1978 [1844]:103).

${ }^{20}$ N.T.: Bairro de entretenimento em Bangkok, Tailândia, que reúne principalmente turistas estrangeiros e expatriados, conhecido internacionalmente como um bairro de prostituição. 
por uma boa outcall ${ }^{21}$, então essa foi uma mudança agradável. ${ }^{22}$

Como Rick e Stephen, esse homem descreve sua experiência, de maneira desembaraçada, como uma forma de consumo comercial leve e não complicada ("duas horas de diversão ilícita", "uma mudança agradável"). Para esse cliente, a prostituição - na qual é tratado com imensa atenção - é, sobretudo, uma diversão financiada pelas, presumivelmente menos prazerosas, atividades profissionais da semana $e$ intercalada de maneira casual entre elas.

Ainda assim, para os clientes, o encontro sexual pago pode também representar algo mais do que apenas uma efêmera indulgência que eles se concedem como consumidores. Em seu artigo "A Fenomenologia de ser um John"23, Holzman e Pines (1982) argumentam que na transação da prostituição o que os clientes estavam comprando era a fantasia de um encontro sexual especial, até mesmo romântico, desejado mutuamente - algo notavelmente distinto tanto de um ato sexual puramente mecânico, quanto de um compromisso romântico, sem limitações, na esfera privada. Em seu estudo, eles observaram que os clientes enfatizaram a afetividade e a cordialidade da trabalhadora sexual como características que eram, no mínimo, tão importantes quanto as particularidades na aparência física. Os clientes por mim entrevistados eram similarmente propensos a expressar variações

\footnotetext{
${ }^{21}$ Outcall e incall são termos do vocabulário do serviço de acompanhantes, onde incall é quando o cliente vai até o local onde se encontra a acompanhante e outcall é quando a acompanhante vai a encontro do cliente.

${ }^{22}$ Embora a prostituição (i.e., contato genital-oral ou genital-genital em troca de pagamento, que constituem atos criminosos perante a legislação do Estado da Califórnia) em clubes de sexo legalizados de São Francisco seja bastante registrada pelos clientes e profissionais do sexo que entrevistei, por clientes em salas de bate-papo online e pela imprensa local, os clubes negam oficialmente que abriguem atividades ilegais (Brook, 1998).

${ }^{23} \mathrm{~N}$. T.: John é o nome genérico atribuído aos clientes.
} 
Desejo, demanda e o comércio do sexo

da afirmação: "se o tratamento dela é frio ou mecânico, eu não estou interessado". Os redatores de guias para clientes de serviços sexuais disponíveis na web, como o "The World Sex Guide", são similarmente críticos às trabalhadoras sexuais que "controlam o tempo", são "muito apressadas e impositivas", que "não querem abraçar ou beijar", ou que "pedem que o sexo seja comum, ordinário".

Embora clientes de diferentes setores do mercado expressem variações desses sentimentos, aqueles que freqüentam estabelecimentos fechados mostraram apreciar a vantagem de uma configuração estruturada para lhes prover, com eficácia, a impressão de uma ligação erótica autêntica. Por exemplo, relações com acompanhantes, em oposição às prostitutas de rua, são usualmente mais prolongadas (durando em média uma hora, ao invés de 15 minutos), mais propensas a acontecer em ambientes confortáveis (um apartamento ou um quarto de hotel, ao invés de em um carro) e mais predispostas a incluir conversas, assim como uma diversidade de atividades sexuais (penetração vaginal, carícias pelo corpo e na genitália, e cunnilingus ${ }^{24}$, e não somente felação simples) (Bernstein, 1999; Lever and Dolnick, 2000). O fato de que no comércio sexual a prostituição de rua constitui, hoje, um setor marginal e em declínio significa que o lugar da transação associada ao "desafogo sexual" rápido e impessoal, cada vez mais está sendo ocupado por outra, configurada para estimular a fantasia de uma reciprocidade sensual, uma fantasia salvaguardada pela concessão do pagamento.

Assim como em outras formas de prestação de serviços, transações sexuais comerciais bem-sucedidas são aquelas em que o aspecto mercadológico do intercâmbio desempenha uma função crucial, estabelecendo limites (Hochschild, 1983; Leidner, 1993). Esse aspecto também pode ser subordinado temporariamente à fantasia do cliente em relação à uma conexão interpessoal autêntica,

${ }^{24}$ N.T.: Tipo de sexo oral na genitália feminina. 
conforme ilustra a descrição, em uma sala de bate-papo, de um encontro em um clube de sexo comercial:

No clube, eu tive uma experiência memorável com uma garota negra de pele clara chamada Luscious... nós nos dirigíamos para a área atrás do palco para uma sessão de serviço completo em uma das minhas visitas. Desta vez eu levei minhas camisinhas. Nós começamos com as carícias íntimas usuais... Eu podia sentir que ela estava ficando muito molhada, o que indicava que seus gemidos não eram fingidos. Vários minutos depois ejaculei e usei para me limpar uma caixa de Kleenex convenientemente localizada. $\mathrm{O}$ mais estranho desse encontro foi que Luscious não pediu o dinheiro adiantado, o que é uma premissa para um lugar desse tipo. Eu lhe dei US\$60 de gorjeta.

Mesmo quando o encontro dura apenas alguns minutos, da perspectiva do cliente, ele pode representar uma forma autêntica $e$ significativa de intercâmbio interpessoal. Sem dúvida, os clientes estão em busca de uma conexão erótica real e recíproca, mas com fronteiras precisas. Para esses homens, o que está sendo comprado (ao menos em termos ideais) é uma conexão sexual que se baseia em uma autenticidade demarcada. Como a invocação acima, que o cliente fez do caráter fisicamente tangível do desejo de Luscious, outros fregueses se gabam da sua habilidade de proporcionar um prazer sexual genuíno às trabalhadoras do sexo, insistem que as que eles contrataram gostavam deles o suficiente para lhes oferecer "cortesias", ou convidá-los para jantar em casa, e proclamam com orgulho que, algumas vezes, até saíram ou se tornaram amigos das trabalhadoras do sexo que estavam encontrando. 
Desejo, demanda e o comércio do sexo
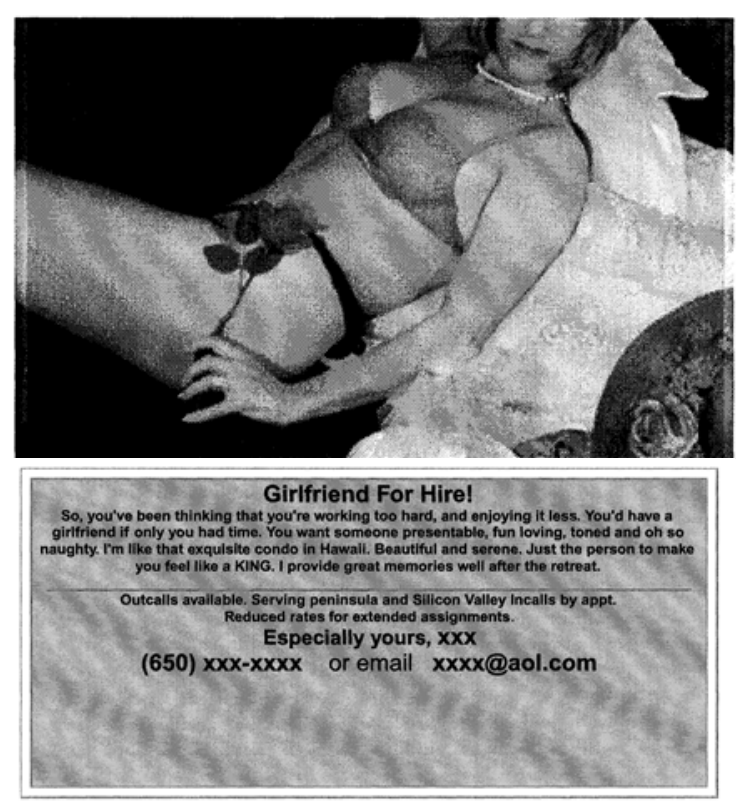

Figure 2 Advertisement from Bay Area web-site. This

advertisement both democratizes access to servile women and promises the 'bounded authenticity' that clients seek.

Figura $2^{25}$ - Anúncio de um website da Bay Area. Este anúncio tanto democratiza o acesso a mulheres servis, como promete a autenticidade delimitada que os clientes buscam.

As reiteradas alegações de uma conexão interpessoal autêntica são particularmente notáveis e é importante levá-las em consideração, uma vez que a grande maioria das trabalhadoras do

\footnotetext{
${ }^{25}$ Aluga-se namorada! Então, você anda pensando que está trabalhando demais, e se divertindo de menos. Você teria uma namorada se ao menos tivesse tempo. Você quer alguém apresentável, amante de diversão, bem torneada e oh! tão safada. Eu sou como aquele cantinho perfeito no Havaí. Linda e serena. A pessoa ideal para fazer você se sentir como um REI. Eu proporciono ótimas lembranças logo após o retiro. Disponível para outcalls. Faz incalls na península e no Vale do Silício. Preços reduzidos para contratos estendidos. Sua XXX.
} 
sexo com quem conversei estabeleciam fronteiras emocionais bastante rígidas entre seus clientes e seus amantes nãoprofissionais. Para as trabalhadoras do sexo, os primeiros quase sempre constituíam uma categoria de identidade geralmente deserotizada, que raramente é transgredida. Uma das poucas trabalhadoras do sexo com quem conversei, admitiu que ocasionalmente procura amantes no seu pool de clientes, disse que já havia aberto mão da prática de oferecer "descontos" ou arranjos sexuais não-pagos para seus clientes prediletos, porque, inevitavelmente, os resultados eram nefastos:

Eles fingem se sentirem lisonjeados, mas nunca voltam! Se você lhes oferece algo diferente de sexo por dinheiro eles fogem. Eu tive um cliente que era tão sexy, um praticante de tai-chi, com quem era realmente divertido trepar. Já que sexo bom é coisa rara, eu the disse que eu o veria por US\$20 (meu preço normal é US\$250). A um outro cara, ele era tão sexy, eu disse "vem de graça". Os dois piraram e nunca mais voltaram. Os homens querem uma ligação emocional, mas não querem ter obrigação alguma. Eles não acreditam ser possível conseguir fazer sexo sem compromissos, e é por isso que eles pagam. Eles preferem pagar do que tê-lo de graça.

Christopher, um trabalhador do sexo masculino que uma vez também tentou redefinir sua relação com um cliente, relatou algo similar:

Uma vez eu liguei para um homem com quem já tinha feito programa porque eu queria fazer sexo com ele de novo... nós concordamos de antemão que seria só o sexo pelo sexo, sem pagar, e aquela foi a última vez que eu ouvi falar dele!

As críticas ao sexo comercializado podem interpretar, inadequadamente, o desejo que os clientes têm de uma 
Desejo, demanda e o comércio do sexo

autenticidade demarcada quando a referência implícita é o paradigma modernista do amor romântico, fundamentado na domesticidade monogâmica e em trajetórias de vida mutuamente entrelaçadas. Nesse sentido, Carole Pateman (1988:199) questiona porque, senão pela pura dominação, "de 15 a $25 \%$ dos clientes das prostitutas de Birmingham exigem aquilo que é conhecido no meio como "bater uma", algo que se presume que poderia ser auto-administrado. Mas como insistiu um cliente, depois de me explicar que ele estudava e trabalhava o tempo todo $e$, conseqüentemente, não tinha muitas oportunidades de conhecer mulheres, ou buscar um relacionamento romântico, "é mais real e humano do que bater punheta sozinho". Esse cliente revela um paradigma sexual subjacente que não é relacional, mas recreativo, compatível com os ritmos do seu cotidiano orientado para si mesmo e, cada vez mais, compatível também com o de outros homens, brancos, de classe média, com perfis sócio-demográficos semelhantes.

\section{O Estado e o redirecionamento do desejo}

São nove horas numa manhã de sábado. Em um das únicas salas ocupadas do Tribunal de Justiça de São Francisco, estou sentada na última fileira da "John School", o programa de pré-julgamento municipal de homens que foram presos por procurar sexo com prostitutas. A cidade se orgulha de seu programa, e se vangloria da baixa taxa de reincidência, menos de $1 \%$ para réus primários, que podem limpar suas fichas por meros US\$500. Há, aproximadamente, de 50 a 60 homens na sala esta manhã, de origens de classe e étnicas diversas (três dos homens ao meu redor estão acompanhados de tradutores: um espanhol, um árabe e um cantonense).

Ainda mais impressionante é que há números quase equivalentes de johns presos e de repórteres na sala. Ao fim da primeira hora, fui apresentada a jornalistas da TV-20, do London Times e da Self Magazine. "Todo mês há 


\section{Elizabeth Bernstein}

representantes de diferentes organizações da mídia aqui", anuncia Evelyn, a agressiva diretora do programa, aos homens. "Eu nunca faço esta aula sem cobertura da mídia". Em contraste absoluto com os johns, as pessoas da mídia são, predominantemente, mulheres de trinta $e$ poucos anos, educadas, estilosas, evidente e intensamente fascinadas pela exibição de tantos homens submissos e dóceis em sua frente, e pela fantasia feminista de ter o jogo de gênero invertido (esses homens estão agora calados e quietos, e pelo menos até as cinco da tarde de hoje, eles estarão forçados a assim permanecer e escutar). Embora eu seja talvez mais consciente do que elas de que testemunhar isso envolve tanto vantagens de classe como uma vitória feminista, também notei a superficial similitude entre essas mulheres e eu.

Ainda de acordo com os johns com que eu conversei durante os coffee breaks, somente alguns estão absorvendo passivamente as informações que lhes foram apresentadas, $e$ estão longe de serem persuadidos da falha de seus hábitos. Os homens dizem que a John School é ainda pior do que a Auto-escola - um dia inteiro de martírio numa sala abafada com toda uma sucessão de oradores igualmente enfadonhos. "Isso é besteira". "Eu fui emboscado". "Essas pessoas são tão hipócritas". "A prostituição deveria ser legalizada". "Eles agem como se fosse algo peculiar, mas todos os homens o fazem... Homens e mulheres só pensam diferente. Os homens vão foder ovelhas, meninos, qualquer coisa. Eles são uns cachorros".

A primeira apresentação é conduzida por um promotor público assistente, e é chamada de "Lei da prostituição e os Fatos da Rua". Ainda que a John School esteja oficialmente disponível para todos os homens presos por procurarem sexo com uma prostituta, a estrutura do programa demonstra que aqueles que foram presos compõem apenas um subgrupo de clientes pequeno e peculiar. Esse programa é claramente voltado para homens heterossexuais que compram sexo na rua. Durante a 
Desejo, demanda e o comércio do sexo

apresentação, o promotor, buscando a participação do grupo, pergunta: "Quantos de vocês foram pegos no Tenderloin? Quantos de vocês foram pegos no Mission? [dois bairros historicamente pobres e, recentemente, passando por um processo de gentrificação ${ }^{26}$, onde há concentração de prostituição de rua]. Ele não se incomoda em perguntar quantos deles foram pegos no teatro erótico local, ou com uma acompanhante, ou navegando em busca de uma trabalhadora do sexo online, ou mesmo na Polk Street [onde há trabalhadoras do sexo transgênero, masculinos e femininas].

O objetivo do promotor é espantar esses homens, para que alterem seus padrões de comportamento, mediante o horripilante detalhamento das possíveis repercussões legais dos seus atos - como é ser indiciado, ir para o camburão, passar a noite na cadeia, ou ser forçado a fazer um teste de HIV - todas conseqüências prováveis de uma reincidência. Ele mostra à audiência um breve vídeo examinando as leis. Num primeiro momento, fico confusa com a última imagem da seqüência: a representação sem legenda de um homem debruçado numa tela de computador. As palavras finais do promotor aos homens são ainda mais inesquecíveis: "Da próxima vez que vocês estiverem pensando em sair para as ruas, façam como esse cara: vão à Internet se precisarem mas fiquem longe de menores!"

A última apresentação, antes da pausa do almoço, traz à cena uma ex-prostituta de rua e ex-viciada em heroína, que agora conduz um programa que ajuda prostitutas a transformarem suas vidas e saírem das ruas. Sentadas ao lado dela estão outras três ex-prostitutas sem-teto e viciadas. Agora livres das drogas e sóbrias, bem cuidadas, bem alimentadas e com vestes conservadoras, suas

${ }^{26}$ N.R.: Gentrificação é um neologismo que remete a processos de transformação do espaço urbano e ocorre, com ou sem intervenção governamental, nas mais variadas cidades do mundo. Gentrification, traduzido como enobrecimento urbano, diz respeito à expulsão de moradores tradicionais, que pertencem a classes sociais menos favorecidas, provocando sua valorização imobiliária. 


\section{Elizabeth Bernstein}

aparências não diferem muito da de outras profissionais de trinta a quarenta anos. Somente sua raiva, expressada de maneira cáustica e veemente, deixa perceber a diferença.

Para os homens, não há dúvida de que este seja o painel mais instigante do dia. Finalmente, prestam atenção, sentados tensos e eretos em suas cadeiras. Pelas suas expressões faciais e posturas inclinadas, alguns até parecem estar levemente excitados. A tática retórica empregada pelas mulheres é uma combinação de terapia de choque e de uma reafirmação incisiva da fundamental importância da domesticidade marital. "A maioria das mulheres com que eu trabalhei começou a fazer programa ainda quando crianças ou adolescentes", declara uma das mulheres com uma voz ríspida e acusatória. "Há muito tempo eu aprendi que não são os pedófilos que estão envolvidos naquilo, mas os homens que estão sentados nesta sala". Com os olhos marejados e os dentes fortemente cerrados, outra jurada conta aos homens sua própria história de abuso sexual precoce, vício e estupro. Sua anedota, teatral, segura a atenção e termina com a seguinte recriminação:

"Houve uma vez, eu me lembro estar com crostas [crusty] e dopada, usando um shorts amarelo, $e$ andando por aí com sangue grudado nas minhas coxas por dois dias. Ninguém me perguntou o que havia de errado. Eu me senti como uma mulher decadente, que Deus, a sociedade e a minha familia nunca perdoariam... A gente não está lá fora porque gosta de chupar um pau, $e$ vocês não estão lá fora porque gostam da gente. Vocês são a causa do nosso sofrimento, $e$ vocês mesmos podem virar estatística. Pesem e percebam, se vocês tiverem que voltar para as ruas - essas mulheres foram judiadas! Muitos de vocês são maridos, pais e avôs. $\mathrm{O}$ que vocês disseram hoje para os seus entes queridos? Com esperança, um dia desses vocês aprenderão a ter relacionamentos saudáveis: com suas esposas".

À tarde há três apresentações adicionais: uma elencada por representantes de grupos de bairro e comerciantes, outra 
Desejo, demanda e o comércio do sexo

com um sargento da Delegacia de Costumes ${ }^{27}$ na questão da cafetinagem, e uma apresentação final de um terapeuta especializado em "Compulsão Sexual e Problemas de Intimidade". Os grupos de bairro estão representados por dois homens e uma mulher, moradores brancos e pequenos comerciantes do distrito de Tenderloin. Junto ao policial, eles pintam os johns como agressores à família, à comunidade, $e$ - ironicamente - ao comércio. ${ }^{28}$ Os danos atribuídos aos johns são simbólicos e materiais. "Você pratica sexo na frente dos seus filhos?", eles perguntam. "os garotinhos do meu bairro enchem camisinhas como bexigas! Se ouve falar em crimes sem vítimas, mas toda a nossa vizinhança é uma vítima! Meninas de quinze anos começam a fazer programa $e$ vinte minutos depois engravidam. Milhões de dólares passam por essas garotas, mas no fim elas não têm nada. Através de todo esse negócio, elas são vítimas".

A sessão final, conduzida por um Orientador da Família e do Casamento autorizado, se baseia no modelo dos dozepassos do dependente sexual, associado ao comportamento do cliente. O orientador é um homem de trinta e tantos anos, branco, de classe média, vestido informalmente, exemplar da cultura terapêutica e da masculinidade de fala suave do norte da Califórnia. Ele começa sua apresentação com uma definição: "Viciados em sexo têm dificuldade em enxergar sexo $e$ amor em conjunto, no mesmo relacionamento. Eles dizem, "Eu amo minha esposa, mas faço sexo com uma prostituta". O desafio é concebê-los junto, aprender como alimentar um relacionamento. Isso não é apenas um assunto de mulher". Depois de distribuir

\footnotetext{
${ }^{27}$ N.R: no original, Vice squad, que remete a esquadrões que combatem pornografia, prostituição, drogas e jogo.

${ }^{28}$ Ruth Rosen observou uma separação semelhante entre os interesses de grandes e pequenos comerciantes no começo do século, enquanto os grandes negócios (agentes imobiliários, proprietários de terras e donos de estabelecimentos e bares) apoiavam prostituição em bordéis, pequenos comerciantes se opunham a isso (Rosen, 1982:77).
} 
um "Teste de Identificação de Dependência Sexual" aos membros da audiência (com perguntas tais como "Você se vê com freqüência ocupado com pensamentos sobre sexo?" e "Sua atividade sexual tem atrapalhado sua vida familiar?").

\section{Teste de Identificação de Dependência Sexual (TIDS)}

O Teste de Identificação de Dependência Sexual (TIDS) foi criado para ajudar na avaliação do comportamento sexual compulsivo ou "dependente". Desenvolvido em parceria com hospitais, programas de tratamento, terapeutas privados e grupos sociais, o TIDS proporciona uma gama de respostas que ajudam a diferenciar os comportamentos dependentes e não-dependentes. Para completar o teste, responda cada pergunta marcando a coluna sim/não apropriada. $^{29}$

${ }^{29} 1$.Você sofreu abuso sexual quando criança ou adolescente? 2.Você assina ou compra regularmente revistas de sexo explícito como Playboy e Penthouse?; 3.Seus pais têm problemas de comportamento sexual?; 4.Você se vê com freqüência ocupado com pensamentos sobre sexo?; 5.Você acha que seu comportamento sexual não é normal?; 6.Sua esposa [ou ente(s) próximo(s)] já se preocupou ou reclamou de seu comportamento sexual?; 7.Você tem dificuldade de interromper sua conduta sexual se a julga inapropriada?; 8.Você já se sentiu mal em relação a sua conduta sexual?; 9.Seu comportamento sexual já causou problemas à sua família?; 10.Você já buscou ajuda em relação a um comportamento sexual que o desgosta?; 11.Alguma vez você já se preocupou sobre o que as pessoas acham das suas atividades sexuais?; 12.Alguém já se feriu emocionalmente em função de seu comportamento sexual?; 13.Alguma de suas atividades sexuais é contra a lei?; 14.Você já prometeu para si mesmo que iria interromper algum aspecto do seu comportamento sexual?; 15.Você já se esforçou para abandonar a prática de uma determinada atividade sexual e falhou?; 16.Você precisa esconder parte de sua conduta sexual de outras pessoas?; 17.Você já se propôs a restringir sua atividade sexual?; 18.Você já se sentiu degradado por seu comportamento sexual?; 19.Sexo tem sido para você uma forma de se esquivar de seus problemas?; 20.Depois de ter relações sexuais você se sente deprimido?; 21.Você sentiu necessidade de interromper determinada forma de atividade sexual?; 22.Sua atividade sexual tem atrapalhado sua vida familiar?; 23.Você já agiu sexualmente com menores? 24.Você se sente dominado por seu desejo sexual?; 25.Você alguma vez já considerou que seu desejo sexual é mais forte do que você mesmo? 
Desejo, demanda e o comércio do sexo

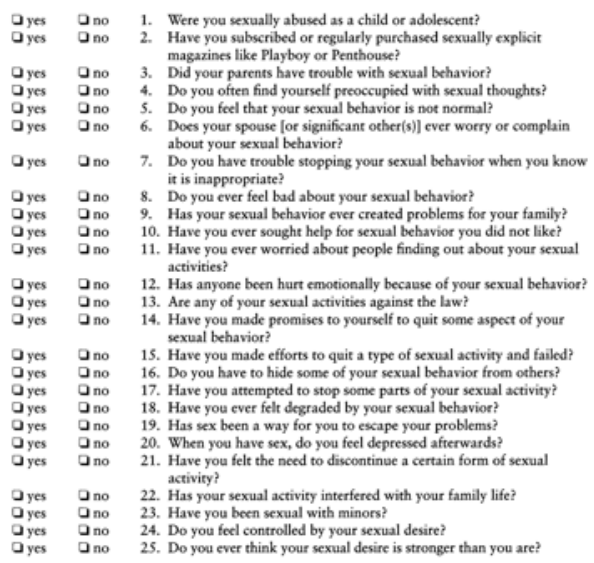

Figura 3 - Teste de Identificação de Dependência Sexual distribuído no Programa de Réus Primários de São Francisco. Originalmente impresso em Patrick Carnes, Contrário ao Amor: Ajudando o Dependente Sexual.

o terapeuta tenta engajá-los em uma discussão sobre o porquê dos homens buscarem prostitutas. "Stress", um homem declara. "Curiosidade", diz o outro. "Raiva? Solidão?", sugere o terapeuta, e alguns deles concordam. Finalmente, um john sai do tédio para um protesto. "Já basta! Isso deveria simplesmente ser legalizado! Os caras precisam de um espaço para aliviar-se". O policial que está sentado à minha esquerda se inclina em minha direção $e$ cochicha no meu ouvido: "Eu concordo. De qualquer modo, eu aposto que a maioria desses homens irão agora para estabelecimentos fechados onde não precisam se preocupar com nada disso" (Caderno de campo, São Francisco, maio de 1999).

$$
* * *
$$

As feministas têm desaprovado, mas também considerado como dado, o duplo padrão sexual no tratamento outorgado à prostituição no sistema de justiça criminal. Recentemente, em 
1993, a acadêmica e ativista pelos direitos das prostitutas, Gail Pheterson (1993:44), argumentou corretamente que:

É claro, o cliente também participa das transações da prostituição e em países onde o comércio do sexo é ilegal, ele é igualmente culpado por um crime. Mas tais leis não são igualmente aplicadas ao cliente e à prostituta... No entanto, em lugar algum a punição aplicada é igualitária, em parte porque oficiais de justiça ou são eles próprios clientes ou se identificam com os mesmos. As prostitutas narram numerosas histórias sobre as demandas sexuais da polícia, de advogados, de juízes e outras autoridades masculinas.

Pheterson e outras críticas nunca poderiam ter previsto que, na metade da década de 1990, governos municipais e federais interviriam a ponto de desafiar e reconfigurar os padrões de consumo masculino heterossexual, e até mesmo mobilizariam argumentos feministas em prol dessas intervenções. Tampouco puderam prever que, apesar de uma identificação de sexo $e$ gênero compartilhada com os clientes, as autoridades masculinas estariam submetidas a outras forças sociais $e$ a interesses políticos que poderiam levá-los a restringir as prerrogativas do desejo heterossexual. E elas não previram que programas como a "John School" e a expansão e diversificação do mercado de serviços de sexo comercial poderiam representar o que aparece como facetas paradoxais de tendências sociais interligadas.

Durante os últimos cinco anos, "John Schools", "Programas de Réus Primários" e "Projetos de Reeducação de Clientes" têm se espalhado por cidades norte-americanas tão diversas como São Francisco e Fresno (Califórnia), Portland (Oregon), Las Vegas (nevada), Buffalo (Nova Iorque). Kansas City (Kansas) e Nashville (Tennessee), assim como em Toronto e Edmonton (Canadá) e Leeds (Reino Unido). Inúmeras outras cidades ao redor dos EUA e da Europa Ocidental estão, no momento, considerando 
Desejo, demanda e o comércio do sexo

implementar programas similares ${ }^{30}$ Depois de descriminalizar a prostituição no final da década de 1960, em 1998, a Suécia se tornou o primeiro governo federal a criminalizar, unilateralmente, o consumo de serviços sexuais por clientes masculinos (Bernstein, 2001). Nos EUA, embora desde a década de 1970 haja gestos esporádicos e passageiros de prisão de clientes masculinos, a reeducação contemporânea de clientes deve ser vista como parte de uma nova estratégia de intervenção estatal no comportamento sexual masculino.

Tanto em Oklahoma quanto em Kansas City, por exemplo, oficiais municipais têm começado a divulgar na televisão a cabo as fotos e os nomes dos clientes masculinos presos pela polícia por delitos relacionados à prostituição (Hamilton, 1999; Weitzer, 2000b). Em Huntington Woods, no Estado de Michigan, a polícia tem liberado os nomes de 16 mil supostos clientes de prostituição em CD-ROM (Associated Press, 1999; Reuters, 1999). Em vários municípios, a polícia também providenciou os nomes de clientes detidos para a publicação em jornais locais, incluindo o Hartford Courant em Connecticut, o Brockton Enterprise em Massachussets e o Kentucky Post em Kentucky (Lewis, 1999). Talvez o exemplo recente mais provocativo (apesar de não estar vinculado ao Estado) de exposição de johns seja o "Webjohn", uma base de dados online organizada por "preocupados membros da comunidade", mostrando filmes de johns, contratando ou se comunicando com uma prostituta conhecida. A "Declaração da Missão" do site, notavelmente, postula os johns, e não as prostitutas, como os vetores da doença, e declara dois objetivos oficiais:

${ }^{30}$ Ver, por exemplo, Marinucci, 1995a e b; Kilman e Watson-Smyth, 1998; Symbaluk e Jones, 1998; Lefler, 1999; Nieves, 1999; Monto, 2000; Weitzer, $2000 b$. 
negar aos johns seu anonimato [e]

oferecer a qualquer vizinhança residencial ou comercial na

América do Norte um mecanismo, isento de custos e livre

de litígios, de supressão da prostituição de rua em sua área.

Juntamente com a retenção do veículo, anulação da carteira de habilitação e proibições mais estritas contra o consumo de prostituição de menores e da posse de pornografia infantil, essa nova enchente de políticas sociais constituem um empreendimento sem precedentes de regulação do comportamento masculino heterossexual (Lefler, 1999; Weitzer, 2000b; Bernstein, 2001).

Allison, Prasad e outros sociólogos, como Castells (1996) e Kempadoo e Doezema (1998), têm apontado, acertadamente, para a rápida expansão da demanda por serviços sexuais comerciais como paradigmática dos diversos elementos-chave do capitalismo tardio: a fusão entre o público e o privado; a extensão em profundidade e escopo do setor de prestação de serviços; a "individualização" do sexo; a predileção por mercadorias impecavelmente delimitadas em detrimento da difusão desregrada do intercâmbio não-mercadológico - o que concebi como "autenticidade demarcada". Mas essas considerações não contemplam o reconhecimento do fato de que o consumo comercial de sexo está sendo simultaneamente normalizado e problematizado, e que estes dois fenômenos estão conectados. Subjacente à falta de atenção à recente criminalização do comportamento do consumidor, dois outros elementos-chave da sociedade do capitalismo tardio são negligenciados: a relação entre a pobreza pós-industrial e a gentrificação, e o impulso normativo de algumas feministas no sentido de reter um modelo modernista de intimidade sexual delimitada de maneira relacional.

As John Schools são o resultado de uma aliança entre ativistas feministas anti-prostituição, organizações sociais de bairro, predominantemente de classe média baixa, e pequenos comerciantes, políticos e grandes negócios interessados no processo de gentrificação de bairros, como os distritos Tenderloin 
Desejo, demanda e o comércio do sexo

e Mission, em São Francisco. Ainda que estejam próximos ao distrito empresarial e a imóveis altamente valorizados, esses bairros abrigam as principais calçadas da prostituição da cidade e os setores mais marginalizados do comércio de sexo. Embora os três grupos indicados tenham diferentes agendas, em termos ideológicos e materiais, eles uniram forças para tornar em alvos os clientes masculinos dos espaços de prostituição mais visíveis publicamente. As campanhas contemporâneas contra a prostituição, contrastando com as disputas morais de um século atrás, estão predominantemente preocupadas em limpar os setores inferiores, com suas questões espinhosas, de uma indústria que, basicamente, não é incomodada, contanto que permaneça atrás de portas fechadas ou, o que é ainda melhor, online (Weitzer, 2000b). Os esforços para erradicar os segmentos mais "problemáticos" da indústria, implicitamente, servem para legitimar as partes não problemáticas que permanecem.

Nesse sentido, o conselho do promotor de justiça do distrito aos freqüentadores da John School - de que deveriam sair de seus carros e recorrer aos seus computadores - pode ser decifrado como um passo importante em direção a ruas mais limpas $e$ bairros gentrificados. Desse modo, em 1994 - quando o Comitê de Supervisores de São Francisco congregou uma força-tarefa para examinar mudanças nas políticas públicas relativas à prostituição na cidade -, o principal incentivo, declarado explicitamente, foi a objeção de moradores e comerciantes a distúrbios em suas ruas (Força-Tarefa sobre a Prostituição de São Francisco, 1994). Neste Relatório Final, a Força-Tarefa registrou que:

Apesar de suas preocupações sobre barulho, trânsito, etc., a maioria dos moradores [dos distritos de Tenderloin $e$ Mission] apoiou a descriminalização ou legalização da prostituição... As válidas preocupações dos moradores acerca da qualidade de vida $e$ o apoio da descriminalização era um conflito mais aparente do que real. O conflito poderia ser solucionado através de um foco nas reclamações: não contra a prostituição em si, mas sobre as 
reações adversas e efeitos colaterais da prostituição de rua

(Força-Tarefa sobre a Prostituição de São Francisco, 1996:27, 29).

Apesar dos representantes da polícia e políticos do município continuarem a enquadrar sua estratégia de fiscalização voltada para as ruas como algo que está de acordo com as reclamações preponderantes dos cidadãos, o efeito dessas políticas é claramente favorável a desviar profissionais do sexo $e$ seus clientes para mercados de sexo indoor e online.

No entanto, o conteúdo ou enfoque moral não está completamente ausente nas novas políticas sociais voltadas para a conduta sexual masculina e para o consumo comercial. As várias correntes da pauta ideológica, que embasa programas como o John School, assim como os grupos de interesses que estão por trás disso, são múltiplas, porém entrelaçadas. Muitas ativistas feministas contemporâneas, assim como suas precursoras feministas, estão dispostas a confrontar a metade masculina do duplo padrão sexual. Dada a manifestação do ideal sexual consumista da Playboy na década de 1960 (Ehrenreich, 1983), a desregulamentação e a normalização da pornografia nos anos 1970 (Juffer, 1998), e outros benefícios da revolução sexual predominantemente masculinos, a reafirmação da domesticidade sexual e da fidelidade marital é experienciada como sendo particularmente crucial. Respondendo a uma constelação semelhante de preocupações, moradores de classe média baixa $e$ pequenos comerciantes também podem ser vistos como participantes de uma "cruzada", ao mesmo tempo material e simbólica, contra a incursão de forças de mercado no interior da ansiada e protegida esfera da família, da vizinhança e da comunidade.

\section{Conclusão}

As duas tendências que documentei aqui, historicamente singulares e contraditórias - o rápido crescimento do consumo e a 
Desejo, demanda e o comércio do sexo

crescente intervenção estatal -, deveriam ser compreendidas no âmbito de um amplo leque de transformações econômicas $e$ culturais que vêm se desdobrando nos últimos trinta anos e se cristalizando com maior expressividade ainda durante os cinco últimos anos. A busca da autenticidade demarcada, encapsulada na demanda pelo comércio do sexo, tem sido ampliada pelo deslocamento de um modelo de intimidade sexual relacional para um modelo recreativo, através da relação simbiótica entre a economia da informação e o consumo de sexo comercial, por meio dos quais o turismo $e$ as viagens de negócios facilitam a inserção de homens no mercado sexual comercial $e$, mais amplamente, pela miríade de fusões $e$ inversões entre as vidas pública e privada, características da nossa era.

Ao mesmo tempo, o fenômeno correspondente da pobreza pós-industrial e da gentrificação do centro conduziram a uma sobreposição de ambições entre políticos municipais, desenvolvimentistas $e$ ativistas feministas anti-prostituição, os quais estão conjuntamente interessados em "fazer uma limpeza" nos desejos masculinos que contribuem para manchar as ruas da cidade. As Johns Schools, assim como outras medidas que penalizam o subgrupo dos clientes masculinos de trabalhadoras do sexo comercial, têm emergido da confluência dessas diferentes pautas políticas. As repressões recentes aos johns e a normalização de outras formas de sexo comercial estão conectadas, porque, além das disputas em torno de sexo e gênero, tanto o policiamento estatal do comércio sexual de rua quanto a normalização do negócio do sexo revelam um esquema compartilhado de interesses econômicos e culturais subjacentes. Ambos, o policiamento nas ruas e a normalização cultural, abrem espaço para o surgimento do setor de serviços pós-industrial e da economia da informação, ajudando a criar espaços urbanos limpos e brilhantes nos quais homens de classe média podem ceder aos seus desejos de consumo de sexo comercial recreativo em segurança. 
Elizabeth Bernstein

\section{Referências bibliográficas}

Allison, Anne. Nightwork: Sexuality, Pleasure, and Corporate Masculinity in a Tokyo Hostess Club. Chicago, University of Chicago Press, 1994.

AssociATED PRESS. Suburban Detroit Police Release Names of Prostitution Ring's Clients. Associated Press, 1/15, 1999 (URL, www.freedomforum.org - last consulted 12 Jan 2000).

BAuman, Zygmunt. On Postmodern Uses of Sex. Theory, Culture \& Society 15(3-4), 1998, pp.19-35.

BERNSTEIN, Elizabeth. Economies of Desire: Sexual Commerce and Post Industrial Culture. Doctoral Dissertation for the Department of Sociology, University of California, Berkeley, 2001.

What's Wrong with Prostitution? What's Right with SexWork? Comparing Markets in Female Sexual Labor. Hastings Women's Law Journal, 10(1),1999, pp.91-119.

BourdiEu, Pierre. Distinction: A Social Critique of the judgement Di Taste. Cambridge-MA, Harvard University Press, 1984.

BrooK, Kerwin. Peep Show Pimps: San Francisco Strip Clubs May be Pushing Dancers into Prostitution. San Francisco Bay Guardian (4), Feb. 1998, pp.18-21.

CARNES, Patrick. Contrary to Love: Helping the Sexual Addict. Minneapolis, Compcare Publishers, 1989.

CASTElls, Manuel. The Net and the SelE: Working Notes for a Critical Theory of the Informational Society. Critique of Anthropology 16(1), 1996, pp.9-38.

DAVIS, Kingsley. The Sociology of Prostitution. American Sociological Review (2), 1937, pp.744-55.

D'EMILIO, John. Capitalism and Gay ldentity. In: SNITOW, Ann; Stansell, Christine and ThOmPSON, Sharon. (eds.) Powers of Desire: The Politics of Sexuality. New York, Monthly Review Press, 1983, pp.110-13.

ECONOMIST, THE. Sex, News, and Statistics: Where Entertainment on the Web Scores. The Economist, 7 Oct. 2000 (www.economist.com - last consulted 19 Oct 2000). 
Desejo, demanda e o comércio do sexo

EHRENREICH, Barbara. The Hearts of Men: American Dreams and the Flight From Commitment. New York, Doubleday, 1983.

ENGELS, Friedrich. The Origin of the Family, Private Property, and the State. In: TUCKER, Robert. (ed.) The Marx-Engels Reader. New York, W. W. Norton, 1978 [1884], pp.734-60.

FASS, Paula. The Damned and the Beautiful: American Youth in the 1920s. Oxford, Oxford University Press, 1977.

Flowers, Amy. The Fantasy Factory: An Insider's View ofthe Phone Sex Industry. Philadelphia, University of Pennsylvania Press, 1998.

GIDDENS, Anthony. The Transformation of Intimacy: Sexuality, Love, and Eroticism in Modern Societies. Stanford-CA, Stanford University Press, 1992.

GREENWALD, Harold. The Elegant Prostitute: A Social and Psychoanalytic Study. New York, Ballantine, 1958.

HAMiLTON, Arnold. Lurid Tactics: Oklahoma City Threatens Prostitution Participants Glare of TV Publicity. Dallas Morning News, 18 March 1999, 33A.

HART, Angie. Missing Masculinity? Prostitutes' Clients in Alicante, Spain. In: Cornwall, Andrea and Lindisfarne, Nancy. (eds.) Dislocating Masculinity: Comparative Ethnographies. New York, Routledge, 1994, pp.48-66.

HOBSON, Barbara. Uneasy Virtue: The Politics of Prostitution and the American Reform Tradition. Chicago-IL, University of Chicago Press, 1990.

HOCHSCHILD, Arlie Russell. The Managed Heart: Commodification of Human Feeling. Berkeley, University of California Press, 1983.

. The Time Bind. New York, Metropolitan, 1997.

HeIGARD, Cecilie and FINSTAD, Liv. Backstreets: Prostitution, Money, and Love. University Park/Pennsylvania State University Press, 1986.

HolzMAn, Harold and PINES, Sharon. Buying Sex: The Phenomenology of Being a John. Deviant Behavior 4, 1982,pp.89-116.

JENNESS, Valerie. Making it Work: The Prostitutes' Rights Movement in Perspective. New York, Aldine de Gruyter, 1993.

JUfFER, Jane. At Home With Pornography: Women, Sex, and Everyday Life. New York, New York University Press, 1998. 
KAY, Kerwin. Male Sexual Clients: Changing Images of Masculinity, Prostitution, and Deviance in the United States, 1900-1950. unpublished ms, on file with author, 1999.

KELLOGG, Susan and MINTZ, Steven. Family Structures. In: CAYTON, M.C. et alii. (eds.) Encylopedia of American Social History, vol. 111, New York, Scribner, 1993, pp.1925-41.

KEMPADOO, Kamala and DOEZEMA, Jo. (eds.) Global sex-workers: Rights, Resistance, and Redefinition. New York, Routledge, 1998.

KILMAN, Lisa and WATSON-SMYTH, Kate. Kerb Crawlers Offered Aversion Therapy Course. Independent (8 March): 5, 1998.

KIMMEL, Michael. Fuel for Fantasy: The Ideological Construction of Male Lust. In: Kerwin, Kay et alii. (eds.) Male Lust: Power, Pleasure, and Transformation. New York, Haworth, 2000, pp.267-73.

KINSEY, Alfred; Pomeroy, Wardell and MARTIN, Clyde E. Sexual Behavior in the Human Male. Philadelphia-PA, W.B. Saunders, 1948.

LANE, Frederick S. Obscene Profits: The Entrepreneurs of Pornography in the Cyber Age. New York, Routledge, 2000.

LASCH, Christopher. Haven in a Heartless World: The Family Besieged. New York, Basic Books, 1979.

Laumann, Edward O.; Gagnon, John H.; Michael, Robert T. and MiCHAELS, Stuart. The Social Organization of Sexuality: Sexual Practices in the United States. Chicago-IL, University of Chicago Press, 1994.

LEARMONTH, Michael. Siliporn Valley. San Jose Metro 15(37), 1999, pp.20-9.

LEFLER, Julie. Shining the Spotlight on Johns: Moving Toward Equal Treatment of Male Customers and Female Prostitutes. Hastings Women's Law fournal, 10(1), 1999, pp.11-37.

LEIDNER, Robin. Fast Food, Fast Talk: Service Work and the Routinization of Everyday Life. Berkeley, University of California Press, 1993.

LEIGH, Carol. Prostitution in the United States: The Statistics. Gauntlet: Exploring the Limits of Free Expression 1, 1994, pp.17-19.

LEVER, Janet and DoLNICK, Deanne. Clients and Call Girls: Seeking Sex and Intimacy. In: WeITZER, Ronald. (ed.) Sex for Sale: Prostitution, 
Desejo, demanda e o comércio do sexo

Pornography, and the Sex Industry. New York, Routledge, 2000, pp.85-103.

LEWIS, Diane. Naming' Johns: Suicide Raises Ethical Questions About Policy. FineLine: The Newsletter on Journalism Ethics 2(6):3, 1999.

LOPEZ, Steve. Hold the Pickles, Please: This Drive- Through Has a New Menu Item. Time (2 Oct):6, 2000.

LUKER, Kristin. Abortion and the Politics of Motherhood. Berkeley, University of California Press, 1984.

LUKER, Kristin. Sex, Social Hygiene, and Syphilis: The Double-Edged Sword of Social Reform. Theory and Society 27, 1998, pp.601-34.

MACDONALD, William. Victimless Crimes: A Description of Offenders and their Prosecution in the District of Columbia. Washington-DC, Institute for Law and Social Research, 1978.

MAnsson, Sven-Axel. The Man in Sexual Commerce. Lund, Lund University School of Social Work, 1988.

MARINUCCI, Carta. International Praise for SF "School for Johns". San Francisco Examiner (14 Nov), 1995a.

A School for Scandal. San Francisco Examiner (16 April), 1995b.

MCINTOSH, Mary. Who Needs Prostitutes: The ldeology of Male Sexual Needs. In: SMART, Carol and SMART, Barry. (eds.) Women, Sexuality, and Social Contrat. London, Routledge, 1978, pp.53-65.

MCKegANeY, Neil and BARNARD, Marina. Sex-work on the Streets: Prostitutes and their Clients. Buckingham, Open University Press, 1996.

MARX, Karl. The Economic and Philosophic Manuscripts of 1844. In: TUCKER, Robert C. (ed.) The Marx-Engels Reader. New York, W.W. Norton, 1978 [1844], pp.66-126.

MonTo, Martin. Why Men Seek Out Prostitutes. In: WeITZER, Ron. (ed.) Sex for Sale: Prostitution, Pornography, and the Sex Industry. New York, Routledge, 2000, pp.67-85.

NIEVES, Evelyn. For Patrons of Prostitutes, Remedial Instruction. New York Times, (18 March), 1999, A1, A20.

O'Connell Davidson, Julia. Prostitution, Power, and Freedom. Ann Arbor, The University of Michigan Press, 1998. 
Pateman, Carole. The Sexual Contract. Stanford-CA, Stanford University Press, 1988.

PHETERSON, Gail. The Whore Stigma: Female Dishonor and Male Unworthiness. Social Text 37, 1993, pp.39-65.

PierRe-PIERRE, Gary. Police Focus on Arresting Prostitutes' Customers. New York Times (20 Nov), 1994.

PRASAD, Monica. The Morality of Market Exchange: Love, Money, and Contractual Justice. Sociological Perspectives 42(2), 1999, pp.181215.

PRIAL, Dunstan. IPO Outlook: Adult' Web Sites Profit, Though Few are Likely to Offer Shares. The Wall StreetJournal (3 Aug), 1999, B10.

PRIEUR, Annick and TAKSDAL, Amhild. Clients of Prostitutes: Sick Deviants or Ordinary Men? A Discussion of the Male Role Concept and Cultural Changes in Masculinity. NORA 2, 1993, pp.105-14.

REUTERS. Names of Alleged US Prostitute Clients Released. Reuters (13 Jan), 1999 (URL www.infonautics.com - last consulted 3 March 2000).

ROSEn, Ruth. The Lost Sisterhood: Prostitution in America'1900-1918. Baltimore-MD, Johns Hopkins University Press, 1982.

SAN FRANCISCO TASK FORCE ON PROSTITUTION. "Interim Report", submitted to the Board of Supervisors of the City and County of San Francisco, California, September 1994.

"Final Report", submitted to the Board of Supervisors of the City and County of San Francisco, California, March 1996.

SCHLOSSER, Eric. The Business of Pornography. US News and World Report (10 Feb), 1997, pp.43-52.

SEIDMAN, Steven. Romantic Longings. New York, Routledge, 1991.

SIMMEL, Georg. Prostitution. In: LeVINE, Donald N. (ed.) On Individuality and Social Forms. Chicago-IL, University of Chicago Press, 1971 [1907], pp.121-6.

SORRENTINO, Constance. The Changing Family in International Perspective. Monthly Labor Review (March), 1990, pp.41-58.

SulLIVAN, Elroy and SimON, William. The Client: A Social, Psychological, and Behavioral Look at the Unseen Patron of Prostitution. In: ELIAS, James; BUllOugh, Vem; EliAS, Veronica and BrEWER, Gwen. (eds.) 
Desejo, demanda e o comércio do sexo

Prostitution: On Whores "Hustlers" and Johns. Amherst-NY, Prometheus Books, 1998, pp.134-55.

SwIDLER, Ann. Love and Adulthood in American Culture. In: SMELSER, N.J. and ERIKSON, E.H. (eds.) Themes of Work and Love in Adulthood. Cambridge-MA, Harvard University Press, 1980, pp.12051.

SYKES, Gresham M. and MATZA, David. Techniques of Neutralization: a Theory of Delinquency. American Sociological Review 22, 1957, pp.664-70.

SYMBALUK, D.G. and JONES, K.M. Prostitution Offender Programs: Canada Finds New Solutions to An Old Problem. Corrections Compendium 23(11), 1998, pp.1-28.

US BuREAU OF THE CENSUS. Studies in Marriage and the Family. Current Population Reports, 23-162, Washington-DC, US Government Printing Office, 1989.

. Marriage, Divorce, and Remarriage in the 1990s. Current Population Reports, Washington-DC, US Government Printing Office, 1992, pp.23-180.

WEEKS, Jeffrey. Inverts, Perverts, and Mary-Annes. In: GELDER, Ken and THORNTON, Sarah. (eds.) The Subcultures Reader. London, Routledge, 1997 [1981], pp.268-81.

WeItZER, Ron. Why We Need More Research on sex-work. In: WeITZER, Ron. (ed.) Sex for Sale: Prostitution, Pornography, and the Sex Industry. New York, Routledge, 2000a, pp.1-17.

The Politics of Prostitution in America. In: WeITzER, Ron. (ed.) Sex for Sale: Prostitution, Pornography, and the Sex Industry. New York, Routledge, 2000b, pp.159-81. 